\title{
V. JAK WYKORZYSTAĆ NARZĘDZIA CYFROWE W PROCESIE WYCHOWANIA? FORMACJA NAUCZYCIELI
}

Wraz z rozwojem technologii cyfrowej do szkół w Polsce już od lat 80. $\mathrm{XX}$ w. stopniowo zaczęły pojawiać się pierwsze komputery. Były całkowitą nowością, choć ich oprogramowanie i możliwości techniczne w tamtych czasach były bardzo skromne. Ich wpływ na proces edukacji w ówczesnej szkole też był raczej niewielki. Kolejna dekada przyniosła pod tym względem ogromny postęp. Komputery szybko stawały się urządzeniami powszechnie dostępnymi, a przy tym z coraz lepszymi parametrami technicznymi. Upowszechnienie się Internetu sprawiło, że możliwości wykorzystania komputerów jeszcze bardziej się rozszerzyły. Odtąd zaczęły odgrywać istotną rolę w procesie komunikacji, w sferze rozrywki oraz w pozyskiwaniu niemal niegraniczonej liczby danych przydatnych w najrozmaitszych dziedzinach życia człowieka. Pedagodzy szybko dostrzegli dużą przydatność komputerów w edukacji, co wpłynęło na rozwój pracowni internetowych w szkołach. Edukacja informatyczna pomagała uczniom zapoznać się z techniką pracy z komputerem, z obsługą programów użytkowych, z posługiwaniem się Internetem, znajdowaniem określonych wiadomości.

Na przestrzeni ostatnich kilkunastu lat obserwujemy duże zmiany w oświacie polskiej, gdy chodzi o wykorzystanie komputerów i Internetu w procesie nauczania. Także dzięki środkom unijnym wprost masowo powstają pracownie komputerowych, a do sal przedmiotowych trafia coraz więcej urządzeń cyfrowych - komputery, rzutniki multimedialne, tablice interaktywne. ${ }^{1}$ Do dyspozycji pedagogów przekazywane są programy edukacyjne do wykorzystania przy użyciu komputera, a także liczne pomoce dydaktyczne. Nowy jakościowo impuls do dalszego rozwoju zastosowania urządzeń cyfrowych w edukacji przyniósł ogólnopolski Program Cyfrowa

W latach 1998-2008 w ramach środków budżetu państwa oraz dotacji unijnych realizowanych w formie projektów wyposażono ponad 30 tys. pracowni komputerowych z dostępem do sieci Internet w różnych typach szkół. Por. Sprawozdanie z realizacji Rządowego programu rozwijania kompetencji uczniów i nauczycieli w zakresie stosowania technologii informacyjno-komunikacyjnych „Cyfrowa szkoła”, Warszawa luty 2014 r., s. 13-14. http://men. gov. pl/wp-content/uploads/2014/02/ sprawozdaniecyfrowaszkola-przyjeteprzezrm25_02_2014. pdf (dostęp: 1 XI 2015 na stronie: http://docplayer. pl/storage/22/1328027/1328027. pdf) 
Szkoła. Jest on realizowany od 2012 r. przez Ministerstwo Edukacji Narodowej oraz Ministerstwo Administracji i Cyfryzacji w wybranych placówkach oświatowych na terenie kraju i należy do priorytetów polskiej polityki oświatowej. ${ }^{2}$ Tylko $\mathrm{w}$ okresie 1,5 roku w ramach pilotażu przeprowadzonego w 402 szkołach na terenie kraju w okresie od 4 IV 2012 r. do 31 VIII 2013 r. wydatkowano na ten cel z rezerwy celowej budżetu państwa łączną kwotę przeszło 46,5 mln zł. ${ }^{3}$ Już same te liczby świadczy o skali zaangażowaniu państwa w proces cyfryzacji szkoły i nakreśla obraz zmian, jakie się w niej dokonują.

Poprawa infrastruktury informatycznej w polskiej szkole przyczyniła się do podniesienia ogólnych kompetencji w zakresie posługiwania się TIK wśród nauczycieli. Trzeba przy tym zauważyć, że generacja starszych nauczycieli przyswaja sobie te umiejętności z większym wysiłkiem. Dla wielu z nich opanowanie sztuki posługiwania się komputerem, rzutnikiem czy tablicą interaktywną, można obrazowo porównać do wyprawy w kosmos w zupełnie inną przestrzeń. Doświadczenie zetknięcia się z możliwościami urządzeń cyfrowych potrafi być fascynujące, ale jednak ta grupa nauczycieli lepiej się czuje, gdy może stosować tradycyjne metody oraz środki dydaktyczne i nie musi na lekcji korzystać z komputerów.

Młodsze pokolenie pedagogów, które już dorastało w warunkach pozwalających na codzienną styczność z komputerem oraz Internetem i to zarówno w domu jak i w szkole, jest pod tym względem w zdecydowanie lepszej sytuacji. Trzeba jednak przyznać, że nawet w tym przypadku umiejętności nauczycieli wciąż jeszcze rzadko wykraczają poza obsługę popularnych przeglądarek internetowych oraz kilku podstawowych programów użytkowych. Gwałtowny postęp techniczny w dziedzinie urządzeń cyfrowych, a także powszechna dostępność komputerów sprawiają, że generacja obecnych uczniów bardzo szybko nabywa umiejętności posługiwania się tymi

2 Program obejmuje następujące obszary: 1. e-nauczyciel - dotyczył rozwijania umiejętności nauczycieli w dziedzinie wykorzystania technologii informacyjno komunikacyjnych (TIK) w nauczaniu, komunikowania się z uczniami oraz ich rodzicami przy użyciu TIK, a także prowadzenia dokumentacji elektronicznej; 2. e-zasoby edukacyjne oraz w tym e-podręcznik; 3. e-szkoła - obejmował działania w zakresie zapewnienie szkołom koniecznej infrastruktury TIK oraz nowoczesnych środków dydaktycznych; 4. e-uczeń - służył stworzeniu uczniom dostępu do nowoczesnych urządzeń TIK, zwłaszcza w środowiskach zagrożonym cyfrowym wykluczeniem; por. tamże, s. 5.

3 Por. tamize, s. 6-8. 
narzędziami. Poziom kompetencji uczniów w zakresie obsługi urządzeń cyfrowych bywa zdecydowanie wyższy niż wielu nauczycieli, dlatego w tym przypadku można mówić o rodzaju inwersji pedagogicznej, ponieważ to uczeń może pomagać nauczycielowi w prawidłowym obsługiwaniu urządzeń cyfrowych na lekcji.

Wobec powyższych spostrzeżeń dotyczących procesu cyfryzacji szkoły można wysunąć kilka przesłanek, które będą przydatne w określeniu kierunku formacji nauczycieli wykorzystania TIK w edukacji:

1. Upowszechnianie urządzeń cyfrowych w edukacji. Ten proces trzeba traktować jako naturalną konsekwencję rozwoju technicznego i kulturowego. Należy się spodziewać jego stałego postępu, co będzie domagało się od nauczycieli podnoszenia umiejętności w zakresie posługiwania się TIK.

2. Dysproporcja kompetencji w zakresie posługiwania się urządzeniami cyfrowymi. Obecnie w kontekście szkolnym możemy mieć do czynienia z sytuacją, w której umiejętności uczniów w zakresie posługiwania się urządzeniami cyfrowymi mogą być większe niż nauczycieli. Dla pedagogów może to być frustrujące, jednak przy mądrej współpracy istnieje szansa uczynienia z tego wartości dodanej. Jeśli nauczyciel będzie umiejętnie wykorzystywał zainteresowania uczniów w tym zakresie i odpowiednio nimi kierował, pozwoli im w ten sposób szybciej się rozwijać. Jednocześnie sam nauczyciel będzie miał dzięki temu szansę doskonalić się w tej dziedzinie.

3. Potrzeba wielostronnego rozwoju pedagogów. Mimo dynamicznego rozwoju technologii cyfrowej nie można formacji nauczyciela skupić jedynie na zdobywaniu kompetencji informatycznych. Komputer nie zastąpi nauczyciela. To urządzenie jest tylko narzędziem, które dopiero w rękach nauczyciela może okazać się skuteczne w procesie dydaktyczno-wychowawczym. Dlatego kompetencje nowoczesnego nauczyciela powinny obejmować nie tylko obsługę urządzeń cyfrowych, ale także umiejętności przedmiotowe, pedagogiczne, psychologiczne oraz humanistyczne. Dzięki temu nauczyciel będzie nadal przewodnikiem dla swoich uczniów w zdobywaniu wiedzy w swojej dziedzinie, a także - jako wzór osobowy - będzie pomagał uczniom w osiąganiu dojrzałości oraz we wkraczaniu w różne obszary życia społecznego. 


\section{Potrzeba wielostronnych kompetencji nauczyciela - „nowoczesnego humanisty"}

Biorąc pod uwagę aktualne wymagania w zakresie dokształcania nauczycieli (każdy nauczyciel powinien przynajmniej raz w roku uczestniczyć w jakimś rodzaju szkolenia w zakresie swojej specjalności bądź w celu nabycia innych kompetencji wymaganych przez dyrekcję szkoły), mogłoby się wydawać, że w tym punkcie wystarczyłoby tylko wskazać kilka przykładów kursów z aktualnej oferty szkoleniowej dla nauczycieli. Zapewne byłoby to także możliwe, jednakże punktem wyjścia podjętej w tym miejscu refleksji są potrzeby odczuwane aktualnie w polskiej szkole. Nie jest rolą tego opracowania dokonywanie oceny funkcjonowania systemu szkoleń dla nauczycieli w Polsce i ich efektywności. Być może jednak wypracowanie pewnych priorytetów oraz harmonizowanie działań długofalowych w zakresie preferowanych kompetencji nauczycieli przyczyniłoby się skuteczności samego procesu formacji. Poniżej nakreślone obszary kompetencji nauczyciela mają charakter postulatu, dzięki któremu łatwiej będzie można zsynchronizować proces wychowawczy podejmowany w szkole z rozwojem edukacji opartej na nowoczesnej technologii cyfrowej.

Kompetencje w zakresie posługiwania się technologią cyfrową w edukacji

Ministerstwo Edukacji Narodowej wraz z realizacją projektów służących rozwijaniu edukacji informatycznej w szkołach podejmowało i nadal podejmuje liczne działania $\mathrm{w}$ zakresie dokształcania nauczycieli. ${ }^{4}$ Podnoszenie kwalifikacji nauczycieli w zakresie posługiwania się urządzeniami cyfrowymi w edukacji należy do priorytetowych zadań ośrodków doskonalenia nauczycieli. ${ }^{5} \mathrm{~W}$ wielu szkołach dyrektorzy oczekują od nauczycieli

4 Prezentowany dokument wymienia $\mathrm{m}$. in. następujące projekty edukacyjne zrealizowane w latach 2004-2006: ,Studia podyplomowe dla nauczycieli w zakresie ICT, języków obcych oraz drugiego przedmiotu”, które ukończyło 20056 nauczycieli; ,Przygotowanie nauczycieli do roli doradcy zawodowego w ramach studiów podyplomowych" (projekt dotyczył m. in. poszerzenia kwalifikacji nauczycieli w zakresie umiejętności posługiwania się technologią informatyczną) - ukończyło 3737 nauczycieli; ,Kursy doskonalące dla nauczycieli w zakresie ICT” ukończyło 16906 nauczycieli; zob. tamże, s. 15.

5 Dla przykładu oferta szkoleniowa dla nauczycieli na 2015 r. zamieszczona na stronie Mazowieckiego Samorządowego Centrum Doskonalenia Nauczycieli 
wykorzystywania na lekcji urządzeń cyfrowych (komputer, rzutnik multimedialny, tablica interaktywna). To także obrazuje, jak wielki wysiłek wkładany jest $\mathrm{w}$ promowanie nowych technologii cyfrowych w obrębie edukacji. W efekcie można zauważyć coraz wyższy poziom wykorzystania środków elektronicznych na lekcji w przeciętnej polskiej szkole. Nauczyciele coraz częściej, chętniej i efektywniej sięgają po środki dydaktyczne w postaci fragmentów filmów, audycji, prezentacji multimedialnych, obrazów, montaży oraz najrozmaitszych zasobów stron internetowych. Wśród pomocy edukacyjnych pojawia się coraz więcej programów na tablice interaktywne oraz do pracy z komputerem. Dzięki temu pedagodzy zyskują nowe, atrakcyjne narzędzia, a jednocześnie sami coraz lepiej opanowują umiejętność posługiwania się najnowszą technologią.

Wprowadzone w wielu szkołach dzienniki elektroniczne wymusiły na nauczycielach opanowanie umiejętności pracy z odpowiednimi programami. Ta forma pozwala na lepszą komunikację z uczniami, a także z ich rodzicami, co może przekładać się na skuteczność procesu edukacji i wychowania w szkole. Zarysowuje się także tendencja do zastępowania tradycyjnych podręczników papierowych e-podręcznikami, które będą o wiele tańsze, a przy tym lepiej dopasowane do oczekiwań uczniów. Wprowadzanie tychże nowości dokonuje się stopniowo i domaga się odpowiedniego przygotowania całej kadry pedagogicznej danej placówki. Wydaje się, że w tym względzie formacja nauczycieli odnosi właściwy skutek i nie ma na tym polu problemów. Trzeba jednak zauważyć, że wprowadzane rozwiązania polegają głównie na wykorzystaniu podstawowych programów użytkowych systemu Windows, rzadziej profesjonalnych materiałów i programów edukacyjnych. Przyjęte zastosowania urządzeń elektronicznych z reguły mają charakter „odtwórczy” - uczniowie otrzymują materiał oraz polecenia zadań do wykonania. Niekiedy też komputery służą do przeprowadzania testów, ankiet, wywiadów itp. - a zatem wszelkich form weryfikowania

w Warszawie Wydział w Płocku zawiera siedem rodzajów szkoleń uwzględniających ogół nauczycieli w zakresie stosowania technologii cyfrowej w edukacji: 1. „Do tablicy! - czyli jak tworzyć własne materiały na tablice multimedialne”; 2. „Edytor grafiki GIMP dla zaawansowanych”; 3. „Otwarte Zasoby Edukacyjne - używaj, kopiuj, zmieniaj, udostępniaj!”; 4. „Prezi, nowe spojrzenie na prezentację”; 5. „Technologie informacyjno-komunikacyjne w pracy nauczyciela przedszkola”; 6 . „Wykorzystanie platformy Moodle w sieci współpracy”; 7. „Wykorzystanie tablicy interaktywnej w nauczaniu różnych przedmiotów"; por. http://www. plock. mscdn. pl/index. php?option=com_wrapper\&view=wrapper\&Itemid=102 (dostęp: 24 I 2015). 
i utrwalania wiedzy. Wykorzystanie zainteresowania uczniów urządzeniami cyfrowymi w sposób twórczy wymaga od nauczyciela szerszych umiejętności w dziedzinie informatyki, a także rozwiniętej intuicji wychowawczej, aby zastosowane rozwiązania służyły rozwojowi ucznia przez nabywanie oczekiwanej wiedzy, umiejętności (także w posługiwaniu się komputerem) oraz postaw osobowych (dojrzałości osobowej).

W wielu przypadkach, jeśli próbuje się zestawiać umiejętności ucznia oraz nauczyciela $\mathrm{w}$ dziedzinie posługiwania się komputerem, komunikowania się czy znajomości programów, to widać wyraźną przewagę tych pierwszych. Dzieci i młodzież uczą się bardzo szybko obsługi tych urządzeń i czynią to wprost intuicyjnie. Co ciekawe, one nie potrzebują tak wielu szkoleń, jak jest w przypadku pedagogów. One funkcjonują w określonej kulturze i szybko poznają możliwości najnowszych urządzeń. Młodzież lubi gadżety, to, co daje dodatkowe efekty. Pod tym względem to wychowawcy muszą stale „nadążać” za tym, co się dzieje w tej dziedzinie. Jeżeli nauczyciel pozwoli się pod tym względem prowadzić uczniom oraz wykaże umiejętnością obserwacji, to ma szansę samemu się rozwinąć, a także wykorzystać wyniesione spostrzeżenia w praktyce pedagogicznej.

Kompetencje w zakresie edukacji medialnej

Zarówno pośród medioznawców jaki w samym społeczeństwie pojawia się coraz częściej postulat, aby w szkole był odrębny przedmiot poświęcony edukacji medialnej. ${ }^{6}$ Nie ulega wątpliwości fakt, że media mają ogromny wpływ na rozwój osoby człowieka, zwłaszcza na sposób jego myślenia oraz postawy moralne. W kontekście wszechobecności mediów w życiu człowieka istnieje coraz pilniejsza potrzeba wprowadzenia takiej formy edukacji. Jej zadanie polegałoby na ukazywaniu głównych zasad działania mediów, na pogłębieniu wiedzy o kulturze medialnej, na kształtowaniu umiejętności dokonywania selekcji komunikatów medialnych oraz krytycznej oceny ich treści, a także na wypracowywaniu własnych poglądów na tematy poruszane przez media. Edukacja medialna powinna zatem wychować ludzi, którzy nie będą bezkrytyczni wobec przekazu medialnego, a tym samym podatni na wielorakie manipulacje. Drugim, ważnym aspektem tego rodzaju kształcenia powinno być rozwijanie u wychowanków umiejętności twórczego wykorzystywania technik medialnych i budowania

${ }^{6}$ Por. P. D r z e w i e c k i, Edukacja medialna a nauczanie religii w szkole, Warszawa 2013, s. 102-104. 
własnych wypowiedzi opartych na takich narzędziach, jak strony internetowe, nagrania audio i wideo, gazetki, prezentacje multimedialne itp. ${ }^{7}$

Obecnie jeszcze nie ma takiego przedmiotu w zestawie szkolnych programów nauczania, jednakże ten rodzaj kompetencji powinien należeć do podstawowych w odniesieniu do pedagogów. Dziedzina mediów jest na tyle szeroka, że każdy z nauczycieli może swobodnie korzystać z jej dobrodziejstw, a jednocześnie uczyć krytycznego odbioru ich treści. Wymaga to, oczywiście, orientacji nauczycieli w zakresie aktualnej oferty mediów, także tego, czym karmią się ich wychowankowie. Nauczyciele powinni także podnosić swoje kompetencje w zakresie wiedzy na temat mediów przez udział w szkoleniach bądź lekturę opracowań poświęconych temu zagadnieniu.

Kompetencje w zakresie rozumienia przemian kulturowych

Kompetencje nauczycieli w dziedzinie dokonujących się przemian kulturowych łączą się wyraźnie z nakreślonymi powyżej kompetencjami medialnymi. W istocie jednak dotykają zagadnienia bardziej ogólnego, ponieważ zmierzają do rozpoznania i zrozumienia zjawisk kulturowych dokonujących się pod wpływem mediów cyfrowych. Wyraźnej zmianie ulega obraz świata, stosunki społeczne, relacje wewnątrz społeczności ludzkiej funkcjonującej jako globalna wioska, a także kondycja człowieka. Współcześnie ta tematyka zaczyna mieć coraz bogatszą literaturę, ${ }^{8}$ która także powinna stać się przedmiotem zainteresowania pedagogów. Po części można traktować ją jako pole dyskusji kulturoznawców, którzy próbują wypracować określone teorie na potrzebę wyjaśnienia współczesnego świata, a zatem wcale nie muszą być uznawane za pewne. Pozwalają one

7 Zob. tamże, s. 119-146.

8 Tytułem przykładu podaję kilka publikacji książkowych, które podejmują wątek przemian cywilizacyjnych, a nawet biologicznych, jakie dotykają człowieka pod wpływem rozwoju mediów cyfrowych: N. C a r r, Plytki umyst. Jak Internet wplywa na nasz mózg, Gliwice 2013; J. v a n D ij k, Społeczne aspekty nowych mediów. Analiza spoleczeństwa sieci, Warszawa 2010; G. H ü th e r, U. H a u s e r, Wszystkie dzieci sa zdolne. Jak marnujemy wrodzone talenty, Słupsk 2014; $\mathrm{S}$. M e e t s c h e n, Cyfrowa duchowość. Wskazówki dla użytkowników, Warszawa 2013; M. S p i t z e r, Cyfrowa demencja. Wjaki sposób pozbawiamy rozumu siebie $i$ swoje dzieci, Słupsk 2013; A. S z e w c z y k, Problemy moralne w świecie informacji, Warszawa 2008; M. Ż y 1 i ń s k a, Neurodydaktyka. Nauczanie i uczenia się przyjazne mózgowi, Torun 2013. 
jednak zauważyć wiele symptomów zmian i poszukiwać ich wyjaśnienia. Skoro zadaniem nauczyciela jest wychowywać człowieka przygotowanego do budowania lepszej przyszłości, to także powinien on mieć jakąś wizję przyszłości, uwzględniającą aktualne tendencje cywilizacyjno-kulturowe.

Wydaje się, że aktualnie nie ma zbyt wielu propozycji formacji nauczycieli w tym zakresie. Należy zatem żywić nadzieję, że jednak znajdą się w ofercie ośrodków doskonalenia nauczycieli, a ci ostatni z kolei będą coraz chętniej wybierali tego typu propozycje. Ten rodzaj wiedzy jest na ogół mało dostępny uczniom oraz ich rodzicom. W obrębie wychowania realizowanego $\mathrm{w}$ warunkach szkolnych uczniowie powinni móc się zapoznać z tematyką przemian cywilizacyjnych, w których sami uczestniczą i których skutki będą odczuwali. Pogłębienie świadomości uczniów w tym zakresie będzie zatem zależało od poziomu kompetencji nauczyciela, jego znajomości problematyki kulturowej i rozumienia czynników wpływających na zmiany w jej wnętrzu.

Kompetencje w zakresie formacji humanistycznej

Nikt już dziś nie ma wątpliwości, że nowoczesne media są nieodzowne w procesie edukacji i wychowania na terenie szkoły. Błędem byłoby jednak skupienie się jedynie na wykorzystaniu tylko i wyłącznie środków TIK we współczesnej szkole. Nie tylko chodzi tu o uzależnienie edukacji od urządzeń technicznych. Skoro cele edukacji zakładają wszechstronny rozwój ucznia, to należy dążyć do kształtowania w nim wielorakich zainteresowań oraz umiejętności. Formacja humanistyczna ucznia powinna oznaczać szeroką wiedzę z wielu dziedzin nauki zarówno z przedmiotów ścisłych jak i humanistycznych. Uczniowie powinni ją zdobywać na wiele sposobów, przez lekturę książek, słuchanie wykładów, dyskusje, ćwiczenia, doświadczenia, inscenizacje, aktywność artystyczną, konkursy itp. Uczniowie sami nie będą w stanie osiągnąć takiego rozwoju korzystając nawet z możliwości oferowanych przez media cyfrowe. ${ }^{9}$

Kompetencje humanistyczne nauczyciela były zawsze podstawą prestiżu i szacunku, jakim cieszył się w opinii społecznej. Składały się na nie szeroka wiedza ogólna, znajomość literatury i sztuki, elokwencja, umiejętność dyskusji na wiele tematów, bogate słownictwo, pomysłowość w zakresie podejmowania inicjatyw o charakterze społeczno-kulturalnym itp. Niezbędnym (wręcz kluczowym) komponentem kompetencji humanistycznych

9 Por. P. D r zew i e c k i, Edukacja medialna, s. 147-161. 
nauczyciela była i jest jego osobowość. Powinien to być człowiek otwarty, przyjazny dla ludzi, ciekawy świata, o wysokim poziomie kultury osobistej, wyznaczający sobie ambitne cele i wymagania, typ zdobywcy (wiedzy) i przywódcy, a przy tym przyjazny przewodnik uczniów, pomagający rozwiązywać ich problemy na poziomie nauki oraz doświadczeń egzystencjalnych.

Tego typu kompetencje zawsze były istotne do formacji uczniów, ponieważ dzięki nim mogli oni rozwijać swoją osobowość. Dziś, skoro uczniowie są narażeni na wychowanie w „cieniu monitora”, tym bardziej potrzebują dobrych przewodników, którzy im pomogą rozwinąć ich osobowość oraz zdolności humanistyczne, aby mogli kształtować wielorakie zainteresowania, stawać się ludźmi potrafiącymi myśleć w sposób samodzielny i niezależny, mającymi szeroką wiedzę ogólną oraz kreatywność. Media cyfrowe przyczyniają się dziś, paradoksalnie, do osłabiania lub wprost zaniku zdolności komunikacji interpersonalnej. Dlatego wśród niezwykle potrzebnych umiejętności ucznia, które powinny być rozwijane w szkole, należy zdolność do komunikowania się z innymi - słuchania innych, pozwalania innym na pełną wypowiedź, budowania logicznych odpowiedzi, posługiwania się dobrym stylem językowym, radzenia sobie z emocjami w rozmowie. Ważne są także kompetencje społeczne uczniów - umiejętność podejmowania odpowiedzialności za innych, angażowanie się w akcje dobroczynne, troska o przestrzeganie prawa i porządku w swoim otoczeniu itp. Osiągnięcie tych efektów domaga się sięgania do tradycyjnych form w edukacji, dlatego nauczyciel nie powinien z nich rezygnować jako już przestarzałych, ale je doskonalić i pokazywać ich wartość dla obecnej edukacji.

\section{Potrzeba harmonijnych szkolnych programów wychowawczych}

Wielostronna formacja nauczycieli zmierzająca do kształtowania „,nowoczesnego humanisty" domaga się także struktur, które pozwolą na realizację ogólnych celów edukacyjnych we współczesnej szkole. Na ogół nie ma problemów w zakresie edukacji w ramach poszczególnych przedmiotów, które można weryfikować przez testy i egzaminy kontrolne. Więcej trudności pojawia się wtedy, gdy chce się zbadać umiejętności ucznia w swobodnym posługiwaniu się wiedzą z różnych dziedzin, dokonywaniu jej analizy i wyprowadzania wniosków. Jeszcze trudniejsze, niemal niemożliwe na poziomie szkoły, jest weryfikowanie cech osobowych ucznia. Temu celowi powinny służyć programy wychowawcze szkoły. 
Tworzenie projektów wychowawczych dla szkoły powinna poprzedzać analiza potrzeb uczniów - jakie są deficyty wiedzy ogólnej oraz odpowiadających nim umiejętności (np. ortografia, czytanie ze zrozumieniem, znajomość dzieł kultury i sztuki, wiedza o kulturze lokalnej), jak je następnie niwelować $\mathrm{w}$ obrębie różnych przedmiotów w ramach korelacji międzyprzedmiotowej (w tym informatycznej). Zapewnienie harmonijnej współpracy nauczycieli, także opartej na wspólnym programie wrażania TIK do edukacji, niewątpliwie może zaowocować podniesieniem efektów dydaktycznych. Podejmowane programy wychowawcze powinny także zakładać działania służące wszechstronnemu rozwojowi osobowości ucznia. Mogą to być np. kompetencje komunikacyjne, w zakresie posługiwania się mediami czy też unikania zagrożeń, z jakimi może się zetknąć młody człowieka w Internecie. Ponadto mogą one dotyczyć wychowania do twórczego spędzania czasu wolnego, rozwijania swoich zainteresowań czy postaw prospołecznych.

Formacja nauczycieli powinna w świetle powyższej refleksji odpowiadać aktualnym potrzebom ucznia i służyć zwłaszcza podnoszeniu kompetencji wychowawczych. Szkoła jest dla dziecka, a zatem jego dobro i wszechstronny rozwój powinny być zawsze punktem wyjścia tworzonych programów edukacyjnych, projektów wychowawczych, budowanej infrastruktury informatycznej oraz formacji nauczycieli. Ten postulat stawia szczególne wymagania wobec polskiego systemu oświaty. Wprawdzie można zauważyć działania, które zmierzają do harmonizowania pracy dydaktycznej i wychowawczej, ale efekty wciąż bywają stosunkowo mało zadowalające. Być może częściowo wynika to z systemu dużych szkół masowych, gdzie uczeń bardzo często bywa zostawiony sam sobie i kontakt wychowawczy w pedagogiem jest ograniczony. Niewątpliwie powinno to być przedmiotem dalszej, wnikliwej refleksji osób odpowiedzialnych za przyszłość polskiej oświaty, a tym samym za przyszłość kolejnych pokoleń Polaków.

$$
* * *
$$

Wraz z rozwojem technologii informatycznych na przestrzeni ostatnich dwudziestu kilku lat bardzo zmienił się obraz szkoły. Wyraźnie zmieniają się potrzeby edukacyjne i wychowawcze ucznia, a w konsekwencji także pojawiają się nowe oczekiwania w dziedzinie kompetencji nauczycieli. Państwo wkłada wiele wysiłku w rozwój infrastruktury informatycznej $\mathrm{w}$ szkole oraz $\mathrm{w}$ podnoszenie kompetencji nauczycieli $\mathrm{w}$ dziedzinie 
posługiwania się TIK. Te działania podnoszą poziom dydaktyki w szkole, przydają atrakcyjności prowadzonym zajęciom, są wyrazem nowoczesności polskiego szkolnictwa. Dokonujące się przeobrażenia polskiej edukacji wymagają jednak dalszego przemyślenia i ukierunkowania, by mogły skuteczniej służyć wychowaniu ludzi światłych, dojrzałych i nowoczesnych. Na podstawie podjętej refleksji można wysunąć następujące postulaty odnośnie formacji nauczycieli w kontekście wykorzystania narzędzi cyfrowych:

1. Podstawowym punktem odniesienia dla programów nauczania i wychowania ucznia powinno być jego dobro i wszechstronny rozwój. Dobre rozpoznanie i zdefiniowanie potrzeb edukacyjnych i wychowawczych ucznia powinno wyznaczać kierunki formacji nauczycieli. Ważnym aspektem współczesnej formacji nauczycieli są kompetencje w zakresie posługiwania się TIK, które także powinny odpowiadać potrzebom lokalnym. Ponadto należałoby także zwrócić uwagę na edukację medialną nauczycieli oraz zadbać o ich wiedzę dotyczącą dokonujących się aktualnie przemian kulturowo-cywilizacyjnych.

2. Ponieważ zadaniem szkoły jest zapewnienie uczniom wszechstronnego rozwoju, istnieje potrzeba koordynowania działań szkoły oraz poszczególnych nauczycieli. Chodzi w tym miejscu o rozwój zrównoważony, który pozwoli poszczególnym uczniom nabycie szerokiej wiedzy oraz różnych umiejętności od humanistycznych, przez techniczne, w zakresie nauk ścisłych, w dziedzinie aktywności fizycznej, w posługiwaniu się urządzeniami cyfrowymi, po komunikację interpersonalną oraz aktywność artystyczną. W tym celu potrzebne jest długofalowe planowanie działań w zakresie wyposażania szkoły w odpowiednie środki, budowania programów wychowawczych, formułowania priorytetów edukacyjno-wychowawczych, aby przyjęte założenia realizować. Opierając się na przyjętych strategiach, można skuteczniej planować oczekiwaną formacje nauczycieli i przeprowadzać na przestrzeni dłuższego czasu. Dzięki takim działaniom (poprawa infrastruktury oraz kompetencji nauczycieli) łatwej będzie można organizować całościowy proces dydaktyczny i wychowawczy w szkole, który będzie służył lepszej koordynacji pracy nauczycieli, a w efekcie rozwojowi uczniów.

3. Propozycje formacji nauczycieli nie powinny zaniedbywać wzbogacania kompetencji wychowawczych oraz rozwijania tradycyjnych umiejętności pedagogicznych. Wobec wyraźnej dominacji środków dydaktycznych opartych na TIK istnieje ryzyko, że uczniowie nie nauczą się samodzielnego myślenia i zdobywania wiedzy z pominięciem urządzeń cyfrowych. Dlatego 
należy dbać o odpowiedni poziom umiejętności pedagogicznych nauczycieli, którzy korzystając $\mathrm{z}$ tradycyjnych narzędzi będą w stanie rozwijać ich wiedzę, umiejętności, a zwłaszcza osobowość. Nauczyciel, który jest autorytetem i potrafi być dobrym wychowawcą, jest dziś szczególnie potrzebny. Jego zadaniem jest bowiem nawiązanie dobrego kontaktu wychowawczego z uczniem i stawanie się dla niego przewodnikiem na drodze rozwoju. Od tego rodzaju postawy nauczyciela będzie także zależało, czy uczeń zdoła ukształtować zdrowe podejście do otaczającej go rzeczywistości, w tym także tej wirtualnej.

ks. Rafat Bednarczyk, Warszawa 